Review

\title{
Pharmacological Importance of Optically Active Tetrahydro- $\beta$-carbolines and Synthetic Approaches to Create the C1 Stereocenter
}

\author{
Aino E. Laine, Christopher Lood and Ari M. P. Koskinen * \\ Laboratory of Organic Chemistry, Department of Chemistry, School of Chemical Tehcnology, \\ Aalto University, PO Box 16100, Kemistintie 1, Aalto FI-00076, Finland; \\ E-Mails: aino.laine@aalto.fi (A.E.L.); christopher.lood@aalto.fi (C.L.) \\ * Author to whom correspondence should be addressed; E-Mail: ari.koskinen@aalto.fi; \\ Tel.: +358-50-555-3310.
}

Received: 19 December 2013; in revised form: 17 January 2014 / Accepted: 20 January 2014 /

Published: 27 January 2014

\begin{abstract}
Tetrahydro- $\beta$-carbolines (TH $\beta \mathrm{Cs}$ ) are a pharmacologically important group of compounds belonging to the indole alkaloids. C1-Substituted optically active TH $\beta$ Cs have been the target of extensive synthetic efforts due to the presence of the scaffold in numerous natural products and synthetic targets. This review briefly summarizes the methods to obtain the $\mathrm{C} 1$ stereocenter and concentrates on evaluating the pharmacological importance of optically active C1-substituted TH $\beta \mathrm{Cs}$, including their PDE5-inhibitory, antimalarial, antiviral and antitumor activities.
\end{abstract}

Keywords: tetrahydro- $\beta$-carboline; TH $\beta \mathrm{C}$; pharmacological importance; biological activity; $\mathrm{C} 1$-substituted TH $\beta \mathrm{C}$

\section{Introduction}

1,2,3,4-Tetrahydro- $\beta$-carbolines (TH $\beta \mathrm{Cs}$ ), a compound class within the indole alkaloids, consist of a variety of both simple and complex natural and synthetic compounds [1]. These compounds possess a vast spectrum of biological activities and their use in novel pharmacological applications is under constant study, as the TH $\beta \mathrm{C}$ structure is present in drugs currently available on the market, drug candidates under development and many other pharmacologically interesting compounds [2-17]. 
One synthetically interesting subgroup among the TH $\beta \mathrm{Cs}$ is the optically active TH $\beta \mathrm{Cs}$ with $\mathrm{C} 1$-substitution. A stereocenter at $\mathrm{C} 1$ is a typical feature in natural $\mathrm{TH} \beta \mathrm{Cs}$ and establishment of this stereocenter has received plenty of attention. C1-Substituted TH $\beta C$ s have a wide variety of pharmacological properties, including PDE5-inhibitory [2], antimalarial [3-9], antiviral [10-13] and antitumor [14-17] activities. This review summarizes the methods to create the $\mathrm{C} 1$-stereocenter and describes the pharmacological activity of simple $\mathrm{C} 1$ substituted TH $\beta \mathrm{Cs}$. This review offers a welcome update to a previous review discussing $\beta$-carbolines [18]. Furthermore, this is the only review focusing on $\mathrm{C} 1$-substituted TH $\beta \mathrm{Cs}$ and this focus allows covering these compounds in more detail.

\section{Structure and Occurrence}

$\beta$-Carboline alkaloids are an important group of natural and synthetic indole alkaloids which all bear the common feature of a tricyclic pyrido[3,4- $b$ ]indole ring structure [19]. The first $\beta$-carboline alkaloid recognized was harmalin, originally isolated in 1841 from Peganum harmala [20], also known as Syrian rue. The occurrence of $\beta$-carbolines in Nature is widespread, presumably due to their simple biogenesis from tryptamine (or tryptophan), and today $\beta$-carbolines have been isolated from various plant families, fungi, animal tissues and marine sources [1]. The fully aromatic members of this group are named $\beta$-carbolines ( $\beta \mathrm{Cs}$ ) $\mathbf{1}$, whereas the members with partially saturated C-rings are known as 3,4-dihydro- $\beta$-carbolines (DH $\beta \mathrm{Cs}) 2$ and 1,2,3,4-tetrahydro- $\beta$-carbolines (TH $\beta \mathrm{Cs}$ ) 3 (Figure 1). The three rings are referred to as $\mathrm{A}, \mathrm{B}$ and $\mathrm{C}$-ring, as labeled in structure $\mathbf{1 .}$

Figure 1. The basic structural units of $\beta \mathrm{C}(1), \mathrm{DH} \beta \mathrm{C}(2)$ and $\mathrm{TH} \beta \mathrm{C}(3)$.

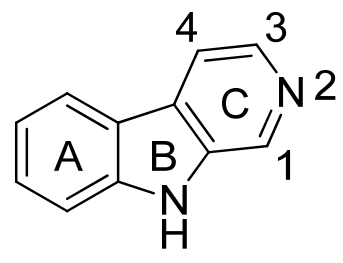

1

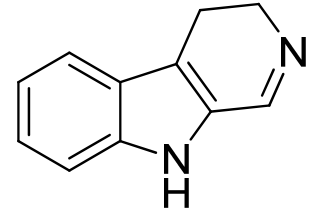

2

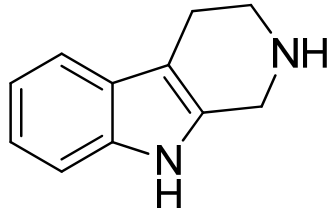

3

The best known natural TH $\beta$ Cs have been isolated from Peganum harmala and Pausinystalia yohimbe (formerly Corynathe yohimbe). Yohimbe alkaloids encompass such pharmacologically interesting natural products as yohimbine and its isomers, reserpine and ajmalicine (Figure 2) the latter two being currently used as antihypertensive drugs. Harmala alkaloids include various $\beta$-carbolines including the TH $\beta$ Cs tetrahydroharmine (an active ingredient in yaje, or ayahuasca, a hallucinogenic brew prepared from the Amazonian plant Banisteriopsis caapi), tryptoline, harmicine and pinoline (a melatonin metabolite produced in the pineal gland) [21]. Today, the most important synthetic compound encompassing the TH $\beta \mathrm{C}$ structure is tadalafil, which has reached almost $\$ 2$ billion annual sales in the treatment of erectile dysfunction under the brand name Cialis [2]. Tadalafil is also used for pulmonary arterial hypertension treatment under the brand name Adcirca. 
Figure 2. Pharmacologically interesting TH $\beta$ Cs.<smiles>CCN1C[C@@H]2C[C@H](OC(=O)c3cc(OC)c(OC)c(OC)c3)[C@H](OC)[C@H]3C[C@H](C[C@H]32)c2[nH]c3cc(OC)ccc3c21</smiles><smiles>COC(=O)C1=COC(C)[C@H]2CN3CCc4c([nH]c5ccccc45)[C@H]3C[C@H]12</smiles>

ajmalicine<smiles>COc1ccc2c3c([nH]c2c1)CNCC3</smiles>

tetrahydroharmine<smiles>[R]c1ccc2[nH]c3c(c2c1)CCNC3</smiles>

$\mathrm{R}=\mathrm{H} \quad$ tryptoline $\mathrm{R}=\mathrm{OMe}$ pinoline<smiles>c1ccc2c3c([nH]c2c1)[C@H]1CCCN1CC3</smiles>

harmicine<smiles>CN1CC(=O)N2C(Cc3c([nH]c4ccccc34)[C@@H]2c2ccccc2)C1=O</smiles>

\section{Biosynthesis}

The biosynthetic route from tryptamine (4) or tryptophan and a carbonyl compound to TH $\beta \mathrm{C} \mathbf{5}$ is simple and the starting materials and their derivatives are widely available in Nature. The reaction from tryptamine to $\mathrm{TH} \beta \mathrm{C}$ is an enzymatic Pictet-Spengler cyclization and several "PictetSpenglerases" have been isolated. The Pictet-Spengler reaction is essentially a two-part reaction (Scheme 1). First, the amine and an aldehyde condense to form an iminium ion. Second, the indole attacks the iminium species from the 3-position, forming a spirocycle that rearranges to a positively charged intermediate which then finally undergoes aromatization via deprotonation to yield the THßC 5 [1,22].

Scheme 1. Biosynthesis of TH $\beta$ Cs.<smiles>NCCc1c[nH]c2ccccc12</smiles>

4 tryptamine

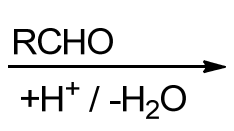<smiles>[R]C[N+]1([CH2-])CCc2[nH]c3ccccc3c2CC1</smiles>

iminium ion<smiles>[R]C1NCCc2c1[nH]c1ccccc21</smiles><smiles>[R]C1NCCC12CCNc1ccccc12</smiles><smiles>[3H]C</smiles><smiles>[13CH-][18CH]</smiles><smiles>[R]C1NCCCC12Nc1ccccc1C21CCCC1</smiles>

In the biosynthesis of indole alkaloids, the carbonyl species is often the iridoid glucoside secologanin. The condensation reaction between secologanin and tryptamine is catalyzed by the enzyme strictosidine synthase (STR). The resultant TH $\beta \mathrm{C}$ strictosidine is a common precursor for a 
number of $\beta$-carbolines as well as other alkaloids, such as ajmalicine, strychnine, reserpine, quinine, catharanthine and vindoline (Figure 3) [22,23].

Figure 3. Alkaloids formed from strictosidine.

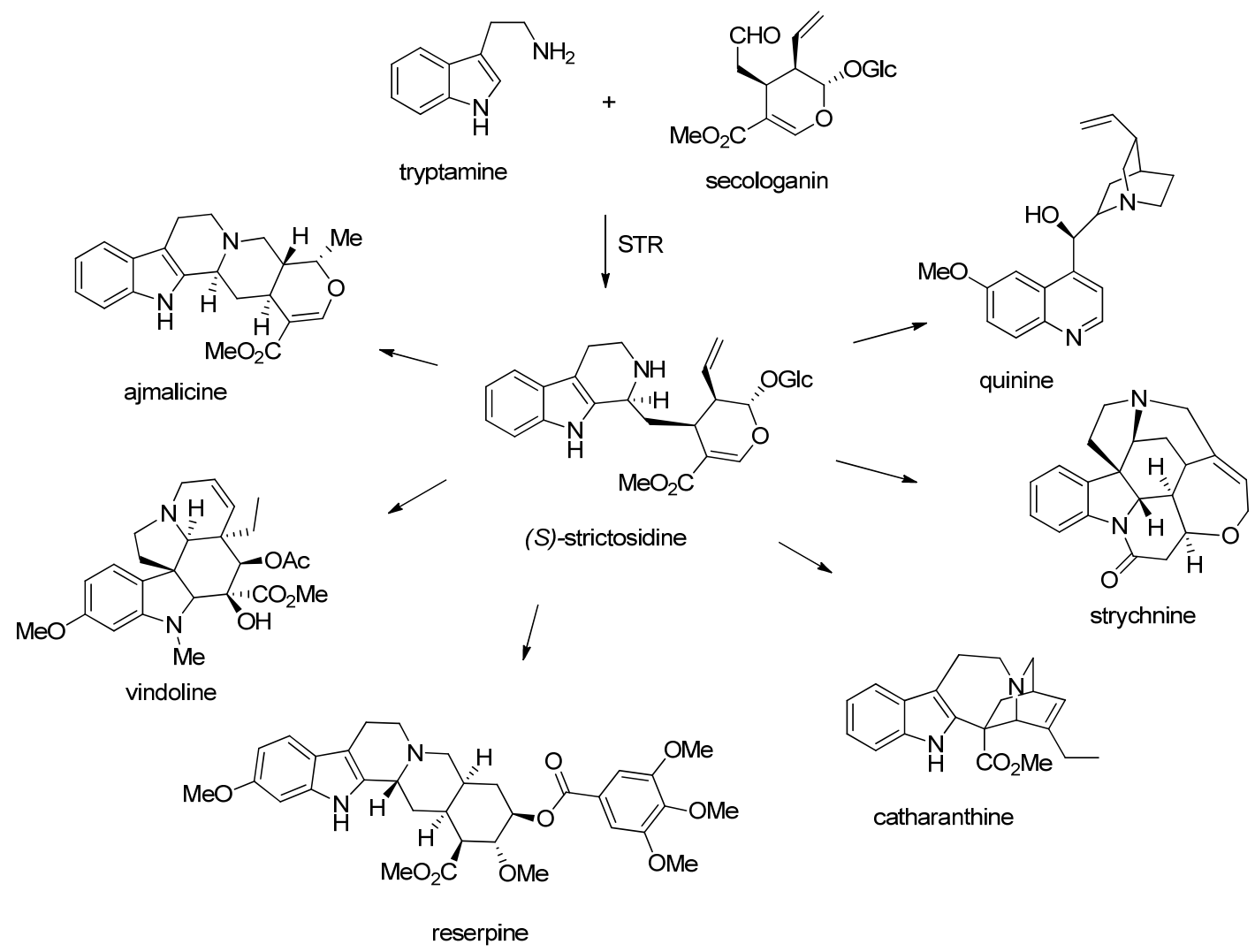

\section{Synthetic Methods to Create the C1 Stereocenter}

The TH $\beta C$ skeleton is found in numerous pharmacologically interesting compounds and hence these alkaloids have been in the focus of synthetic efforts for a long time. The most popular synthetic routes utilize the Pictet-Spengler cyclization [24] (extensively reviewed in 1995 by James Cook [25] and more recently by Joachim Stöckigt in 2011 [23]) that could be considered as a biomimetic approach. Alternatively, a rather similar Bischler-Napieralski cyclization [26] can be used. In a Bischler-Napieralski reaction, a tryptamide 6 is cyclized. Usually dehydration reagents, such as $\mathrm{PCl}_{5}$, $\mathrm{POCl}_{3}, \mathrm{SOCl}_{2}$ or $\mathrm{ZnCl}_{2}$, are needed to promote the loss of the carbonyl oxygen. The product of the Bischler-Napieralski reaction is a $\mathrm{DH} \beta \mathrm{C} 7$ which can then be further reduced to form the corresponding TH $\beta \mathrm{C} 5$ (Scheme 2).

Scheme 2. A general Bischler-Napieralski cyclization and reduction to TH $\beta C$.

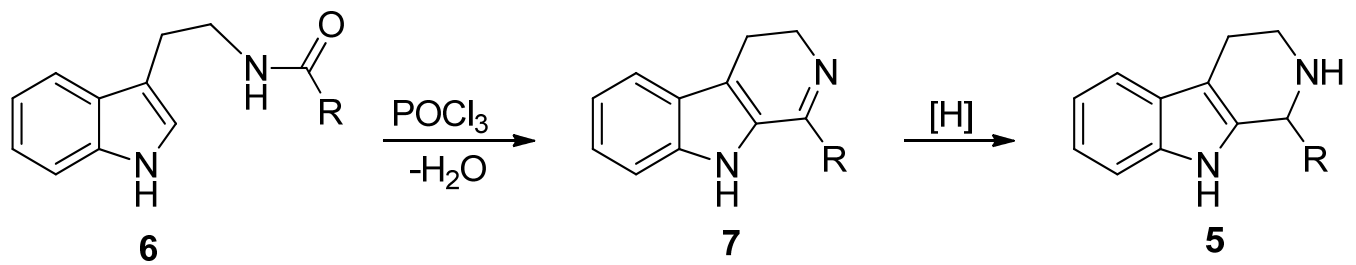


Chirality can be introduced to the $\mathrm{DH} \beta \mathrm{C}$ product by using asymmetric reduction protocols. Asymmetric transfer hydrogenation (ATH) using Noyori -type catalysts [27] offers a powerful method of accessing a chiral TH $\beta C$ skeleton. Due to the highly stereoselective nature of the reaction in question, this remains one of the most commonly employed procedures. Classical Noyori conditions use an azeotropic mixture of $\mathrm{Et}_{3} \mathrm{~N}$ and $\mathrm{HCOOH}$ as the hydrogen source to reduce compound $\mathbf{8}$ to the corresponding chiral TH $\beta \mathrm{C} 9$ (Scheme 3).

Scheme 3. Classical Noyori ATH conditions [27].
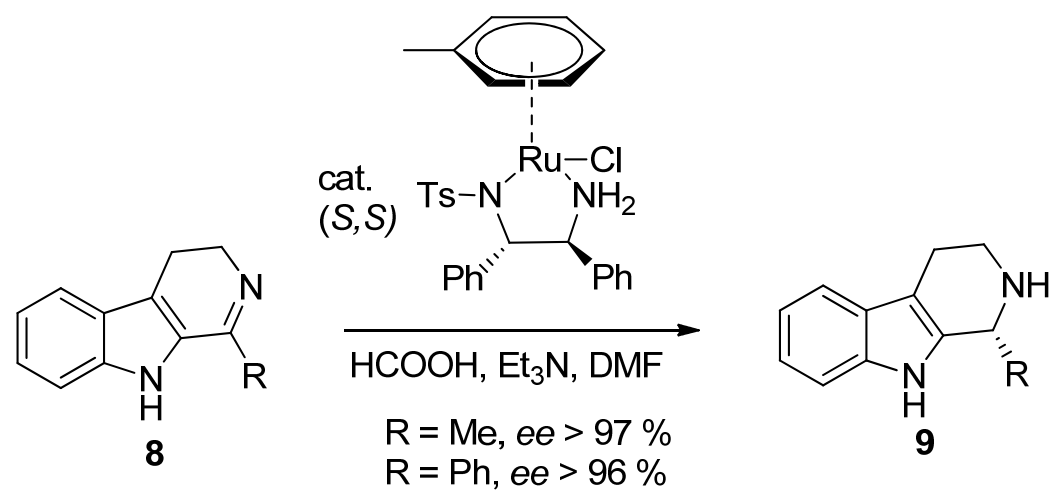

In addition to $\mathrm{ATH}$, the stereochemistry of the reduction product can be controlled also by preexisting directing moieties in a diastereoselective fashion. In Woodward's classic total synthesis of reserpine [28], published in 1958 (Scheme 4), a Bischler-Napieralski reaction from amide $\mathbf{1 0}$ to DH $\beta C$ 11 was followed by a $\mathrm{NaBH}_{4}$ reduction selectively forming $\mathrm{TH} \beta \mathrm{C} \mathbf{1 2}$. Interestingly but not very surprisingly, this reduction selectively yielded the wrong diastereomer. However, in this case the configuration at $\mathrm{C} 1$ could be inverted at a later stage of the synthesis.

Scheme 4. Bischler-Napieralski reaction and diastereoselective reduction in the total synthesis of reserpine [28].<smiles>COc1ccc2c(CCN3CC(=O)C[C@H]4C[C@H](OC(C)=O)[C@@H](C(C)=O)[C@H]4C3)c[nH]c2c1</smiles>

10

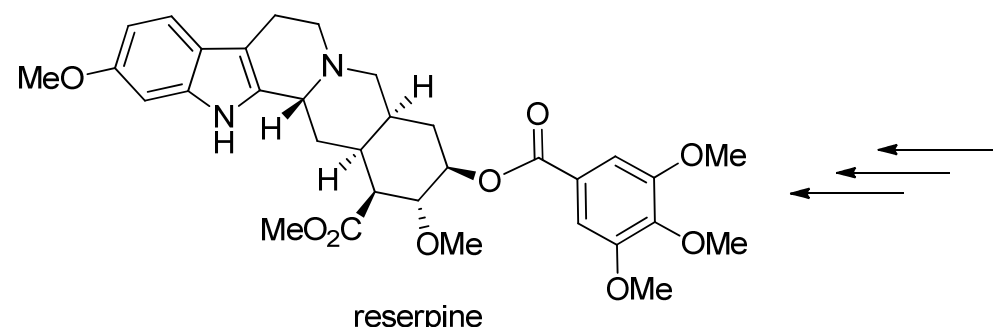
reserpine

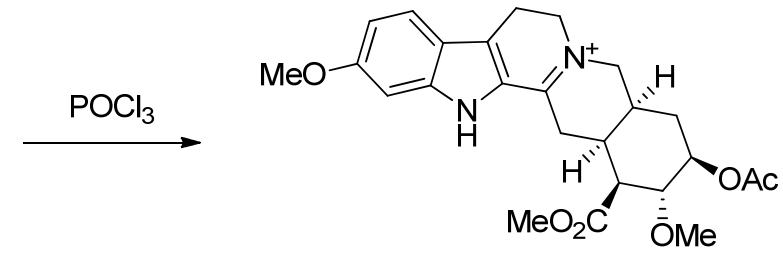

11

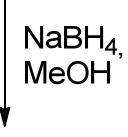

$\mathrm{NaBH}_{4}$
$\mathrm{MeOH}$

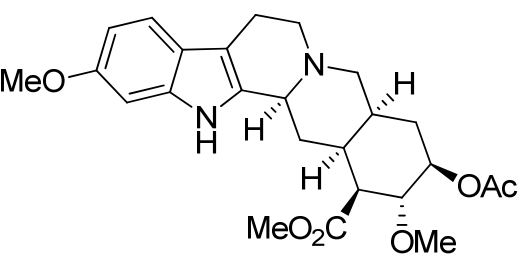

12 
The stereochemistry in the TH $\beta \mathrm{C}$ s can also be controlled by using chiral inductors in the PictetSpengler reaction. Internal induction as a means to control the stereochemistry at $\mathrm{C} 1$ uses chiral starting materials that are often derived from tryptophan. The existing stereochemistry guides the formation of the second chiral center in cases when $\mathrm{C} 1$ is substituted [29,30]. The diastereoselectivity of Pictet-Spengler reaction has been studied and discussed in detail by Bailey and Cook [25,31]. The conformation of the spiroindolenine intermediate determines whether a trans- or a cis-product is formed (Scheme 5). The trans-product is predominantly formed under thermodynamic control and under kinetic control the selectivity is turned towards the cis-product. However, the overall control of the cis/trans-selectivity is very complicated; in addition to the reaction temperature, the substitution pattern together with the size and electronic properties of the substituents have a considerable impact on the selectivity.

Scheme 5. Formation of cis- and trans-products from the spiroindolenine intermediate. $\mathrm{a}=$ axial, $\mathrm{e}=$ equatorial.

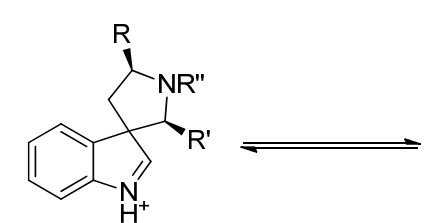<smiles>[R]C1Cc2ccccc2[CH][C@]1([R])CN(C)C</smiles>

$=$

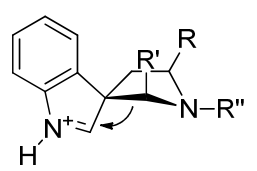

$=$
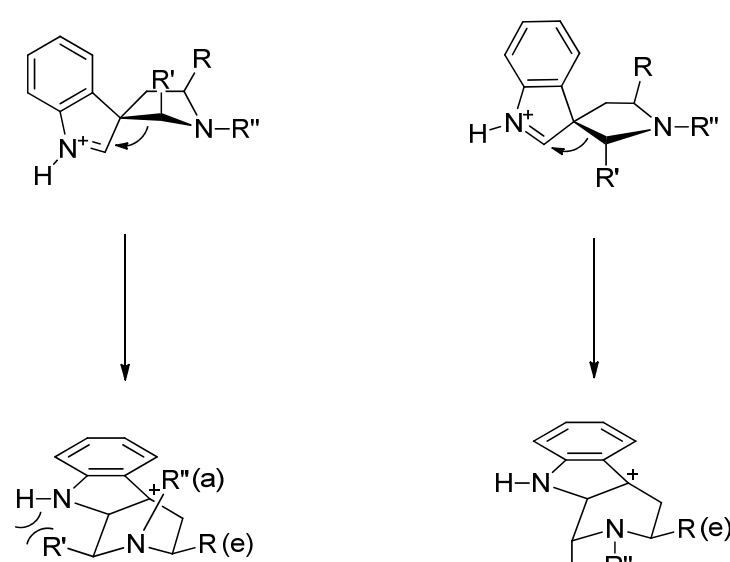

(e)

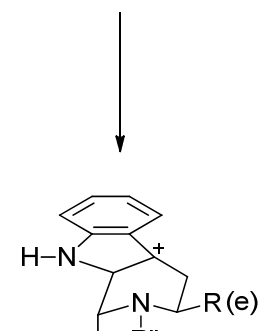

$=$

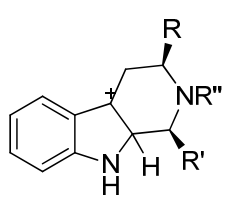

cis-product

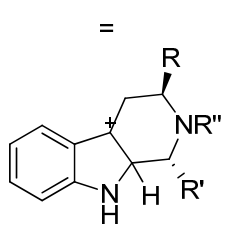

trans-product

Despite the complicated nature of this type of internal chiral induction, the reaction outcome has the potential of being highly stereoselective. It has been used extensively in indole alkaloid synthesis to control the stereochemistry at C1 [30,32]. An early example of successful use of internal induction is found in the ajmaline synthesis by Cook (Scheme 6) [33]. In this work, tryptophan benzyl ester 13 was used for the Pictet-Spengler reaction. The yield of the trans-product $\mathbf{1 4}$ was enhanced by acid induced epimerization that was conducted simultaneously with the Pictet-Spengler reaction. 
Scheme 6. Synthesis of ajmaline by Cook [33].<smiles>Cn1cc(C[C@H](N)C(N)=O)c2ccccc21</smiles>

13

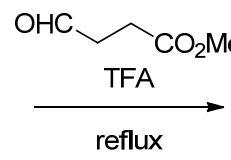

reflux

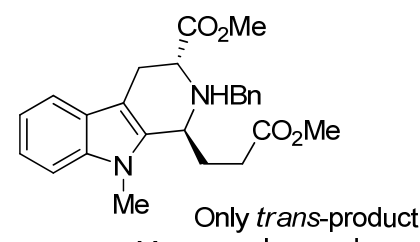

14 was observed

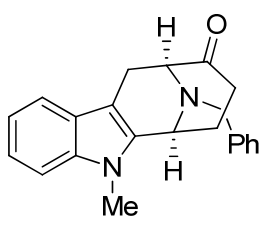

15

The key in the epimerization is a reversible ring opening that favors the thermodynamically more stable trans-product (Scheme 7). Hence, a reliable protocol exists to yield trans-product in very high selectivity from N2 benzyl substituted tryptophan derivatives. The same strategy to reach intermediate $\mathbf{1 5}$ has been successfully used to synthetize other related alkaloids such as 11-methoxymacroline and alstophylline [34].

Scheme 7. Epimerization of 1,2,3-substituted TH $\beta$ Cs favor trans-product.<smiles>[R]OC(=O)[C@@H]1Cc2c([nH]c3ccccc23)[C@@H]1[R]</smiles><smiles>CC#CC</smiles><smiles>[R]OC(=O)[C@@H]1C[C]([R])c2[nH]c3ccccc3c2C1</smiles><smiles>C=CC</smiles><smiles>[R]OC(=O)[C@H]1Cc2c([nH]c3ccccc23)C([R])[15CH]1</smiles>

Bailey et al. have studied kinetically controlled Pictet-Spengler reactions and found that in addition to trans-selectivity, under suitable reaction conditions and substitution pattern, the Pictet-Spengler reaction can become highly cis-selective [31]. In a representative example (Scheme 8), the cyano substituent in the tryptophan derivative $\mathbf{1 6}$ is necessary for the reaction outcome to achieve good cisselectivity, to form product $\mathbf{1 7}$. The kinetically controlled reaction has been subsequently used e.g., in (-)-raumacline synthesis [35] and the conditions leading to the cis-selectivity have been studied thereafter [36,37].

Scheme 8. The Kinetically controlled Pictet-Spengler reaction in (-)-raumacline synthesis [35].<smiles>N#CCC(N)Cc1c[nH]c2ccccc12</smiles>

16

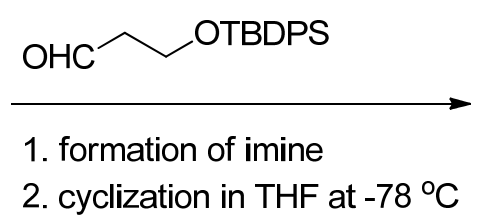

2. cyclization in $\mathrm{THF}$ at $-78^{\circ} \mathrm{C}$<smiles>N#CCC1Cc2c([nH]c3ccccc23)C(CCO[Pb])N1</smiles>

Only cis-product was observed 
In addition to a directing group at $\mathrm{C} 3$, also chiral auxiliaries on $\mathrm{N} 2$ have been studied as an alternative. A benefit of an auxiliary on the nitrogen would be the easy attachment and removal of the chiral auxiliary. However, simple benzyl- or naphthyl-derived chiral groups provide only moderate diastereoselectivity and only $30 \%-80 \%$ de [38,39]. Yet, good diastereoselectivities have been obtained using $N, N$-phthaloylamino acids (Scheme 9) [40]. In this example the pre-formed imine $\mathbf{1 8}$ is protected with a phthaloylamino acid derivative and the $N$-protected TH $\beta \mathrm{C} \mathbf{1 9}$ is formed diastereoselectively.

Scheme 9. Asymmetric Pictet-Spengler using chiral N2-auxiliary [40].
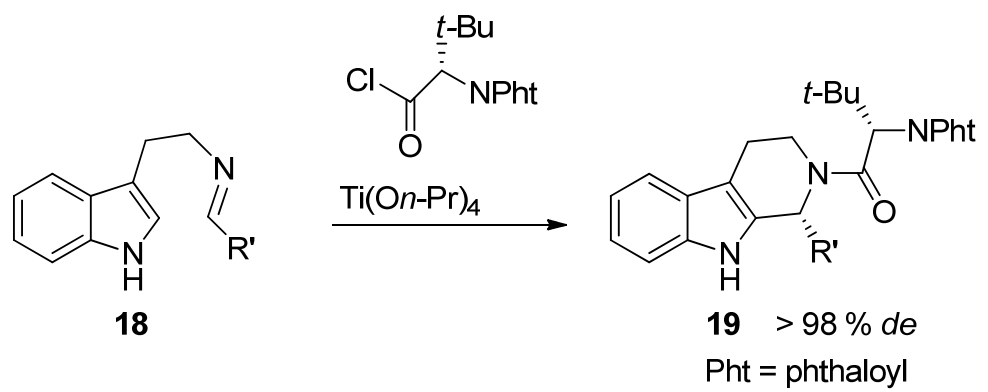

Moreover, the source of stereochemical information in Pictet-Spengler reactions can be from chiral carbonyl compounds. Ducrot et al. condensed tryptamine $\mathbf{4}$ with a chiral aldehyde $\mathbf{2 0}$ derived from Lglutamic acid (Scheme 10) [41]. The preferred cis-compound 21 was formed exclusively when a carboxybenzyl $(\mathrm{Cbz})$ protecting group was used $(\mathrm{R}=\mathrm{Cbz})$ and the selectivity was turned towards the trans-product 22 when the amine was protected with a pyrrole. Ducrot et al. speculated that the size of the protecting group is an important factor, but since pyrrole and $\mathrm{Cbz}$-protecting groups are rather similar in size it seems more likely that this selectivity is guided by other factors.

Scheme 10. Pictet-Spengler reaction with chiral carbonyl species [41].<smiles>NCCc1c[nH]c2ccccc12</smiles>

4

$+$<smiles>[R]N[C@@H](C=O)CCC(=O)OCc1ccccc1</smiles>

20

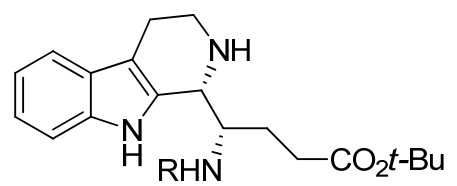

21, cis-product
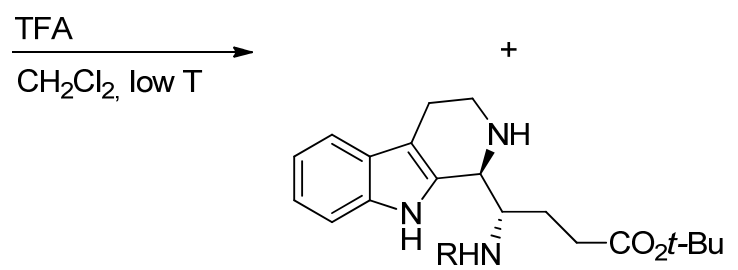

22, trans-product

External asymmetric induction can also be used in the Pictet-Spengler reaction. The first enantioselective Pictet-Spengler reactions using external asymmetric induction were conducted in 1996 by Kawate et al. using diisopinocampheylchloroboranes and reaching 90\% ee [42]. Today, various asymmetric reagents have been used for Pictet-Spengler reactions providing moderate to high ee:s. In recent publications, popular catalysts in asymmetric Pictet-Spengler reactions includes thiourea based catalysts $[43,44]$ and chiral phosphoric acid diesters $[45,46]$ (Scheme 11). 
Scheme 11. Pictet-Spengler reaction using external asymmetric induction [45].

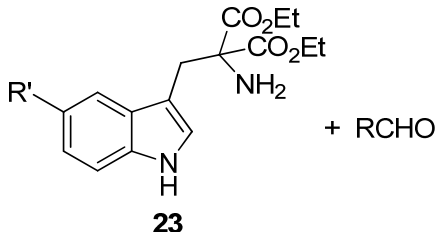

23

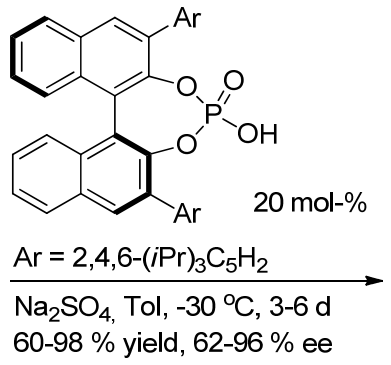

$60-98 \%$ yield, 62-96 \% ee

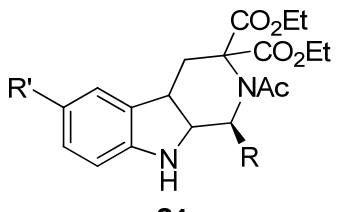

24

Despite the amount of publications related to asymmetric Pictet-Spengler reaction with external asymmetric induction, these methods have several limitations: the $\mathrm{C} 1$ substituent usually has to be rather bulky in order to achieve $>80 \%$ ee's; reaction times can increase to several days and the catalyst loading is often rather high, $>10 \%$.

While Pictet-Spengler and Bichler-Napieralski reactions are the most common methods to build the TH $\beta C$ scaffold, domino reactions incorporating the Heck reaction have also been suggested as a possible approach [47,48]. Recently, Pfeffer et al. reported domino Heck-aza-Michael reactions with asymmetric induction [49]. The method provided related $\mathrm{N}$-heterocycles such as tetrahydroisoquinolones with good de, however, TH $\beta$ Cs were obtained with a modest $60 \%$ de only (Scheme 12).

Scheme 12. Domino Heck-aza-Michael reaction with asymmetric induction [49].<smiles>CCCCCCC(Cc1c(Br)[nH]c2ccccc12)N[Pb]</smiles>

25

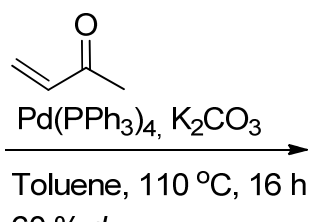

$60 \%$ de

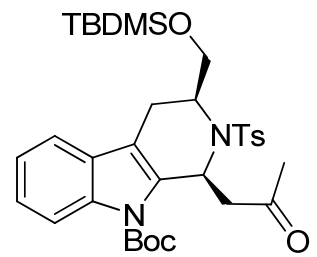

26

Another example of establishing the $\mathrm{C} 1$-stereocenter has been demonstrated by Meyers et al. in their total syntheses of (+)-deplancheine and (-)-yohimbine [50,51]. In their work, C1-substitution was introduced at a later stage using the N2-auxiliary as a directing group (Scheme 13). With this method high ee's were obtained.

Scheme 13. Asymmetric alkylation to $\mathrm{C} 1$ [51].<smiles>CCCOC[C@H](N=CN1CCc2c(n(COC)c3ccccc23)C1)C(C)C</smiles>

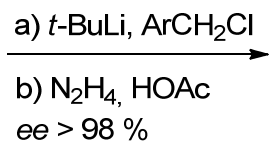
ee $>98 \%$<smiles>COCn1c2c(c3ccccc31)CCNC2Cc1cccc(OC)c1</smiles>

\section{Pharmacological Importance}

This chapter concentrates on the pharmacological importance of $\mathrm{C} 1$-substituted TH $\beta \mathrm{Cs}$. As the skeleton is a common feature in many natural and synthetic compounds, both the multitude of compounds belonging to this group as well as their corresponding biological activities is vast. The 
review emphasizes recent studies rather than more traditional applications of TH $\beta$ Cs. The biochemical and pharmacological functions of $\beta$-carbolines (including TH $\beta C$ s) has been reviewed in 2007 [18] as well as the pharmacological importance of indole alkaloid marine natural products in 2005 [52].

\subsection{Antiprotozoal Activity}

Several TH $\beta$ Cs have been reported to exhibit antiprotozoal, most notably antimalarial, activity (Figure 4). Malaria is one of the most important infectious diseases in the world. According to the World Health Organization (WHO) 200-300 million people are infected and 1.5-2.5 million people die of malaria annually. Some $90 \%$ of malaria deaths occur in Africa and $85 \%$ of the deceased are younger than 5 years-old [53]. Malaria is caused by red blood cell infecting protozoan parasites belonging to the Plasmodium genus, mainly Plasmodium falciparum [54]. Traditionally, malaria has been treated with quinine type drugs such as chloroquine. However, the emergence of drug resistant strains has created new challenges for efficient treatments [55]. Several recent studies have focused on the use of different TH $\beta C$ type compounds in the treatment of malaria [3-9].

$(+)$-7-Bromotrypargine (29) is a marine natural product that was recently isolated from a sponge, Ancorina sp. Davis et al. reported the isolation and the structural elucidation of the compound together with tests towards antimalarial activity [3]. The compound was tested against both chloroquineresistant (Dd2) and chloroquine-sensitive (3D7) strains of $P$. falciparum and (+)-7-bromotrypargine was shown to display $\mathrm{IC}_{50}$ values of $5.4 \mu \mathrm{M}$ (Dd2) and $3.5 \mu \mathrm{M}$ (3D7). Similar compounds were also studied by Chan et al. and moderate antimalarial activity was reported [4].

Figure 4. TH $\beta \mathrm{Cs}$ with antiprotozoan properties.
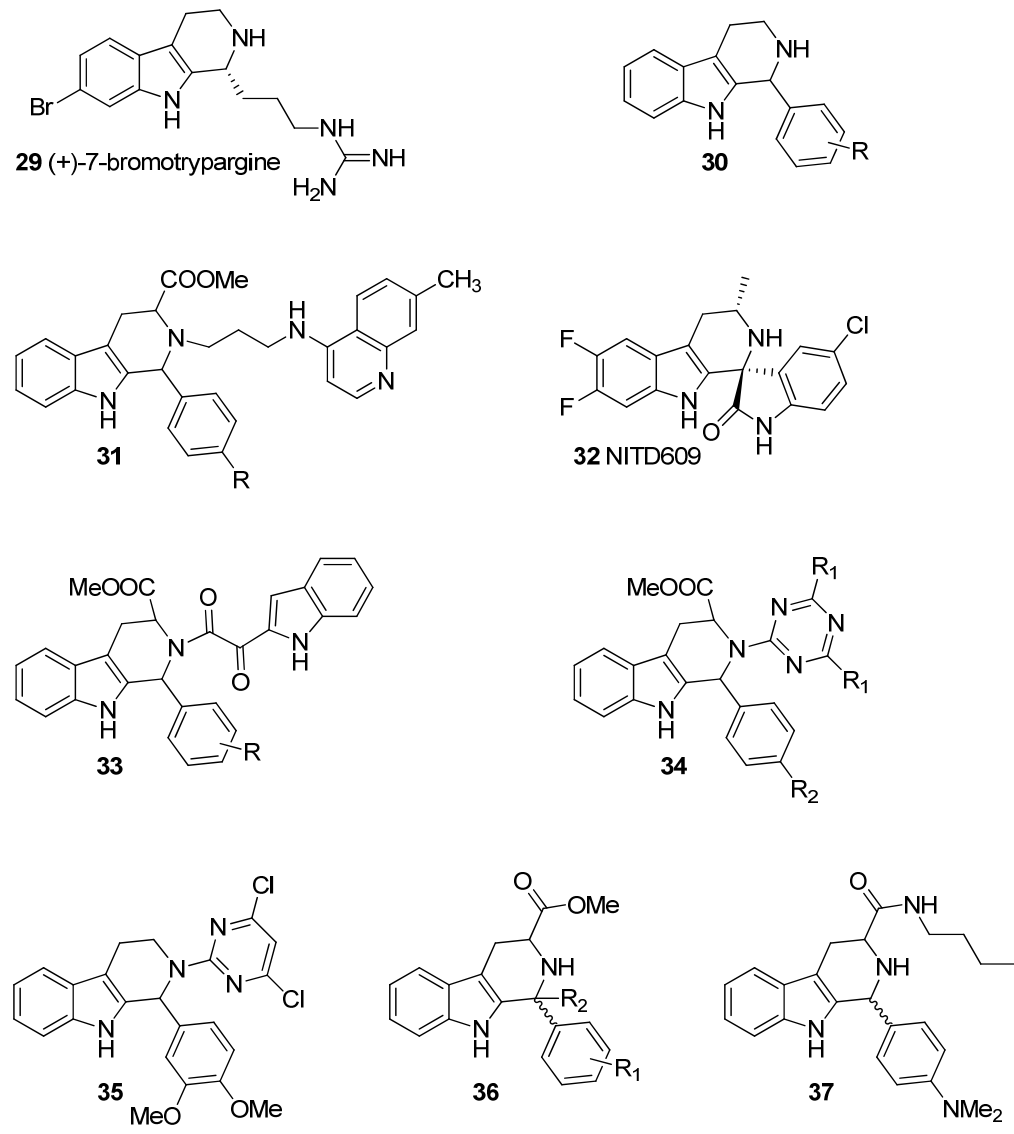
In 2012, Gellis et al. synthesized a series of simple 1-substituted TH $\beta \mathrm{C}$ derivatives with the general structure 30 with one or more substituents on the phenyl moiety. They tested a series of 20 compounds against the W2 culture adapted strain of $P$. falciparum resistant to chloroquine, pyrimethamine and proguanil and nine compounds showed antiplasmodial activity. The most active compound was a para-methoxy-substituted one with $\mathrm{IC}_{50}$ of $0.7 \mu \mathrm{M}$ (W2 $\mathrm{IC}_{50}$ of chloroquine $0.7 \mu \mathrm{M}$ ) [5].

In 2008, Gupta et al. synthesized a series of chloroquine-TH $\beta \mathrm{C}$ hybrid molecules with the general structure 31. Altogether 23 compounds were screened against chloroquine sensitive $P$. falsiparum strain and the most active compounds had $\mathrm{R}=i-\mathrm{Pr}, \mathrm{R}=\mathrm{Me}$ and $\mathrm{R}=\mathrm{Et}$ and showed minimum inhibitory concentrations (MIC) of $0.05,0.06$, and $0.11 \mu \mathrm{M}$, respectively, thus showing significantly greater activity than the standard drug chloroquine $(\mathrm{MIC}=0.391 \mu \mathrm{M})[6]$.

A new class of potent antimalarials that has recently gained attention are spiroindolones with a TH $\beta C$ structure. In 2010, these types of compounds were recognized as antimalarials in high-throughput screenings by the Novartis Institute of Tropical Diseases [7,8]. These compounds act against $P$. falciparum with a mechanism distinct from that of the existing antimalarial drugs [7] and the optimized lead compound NITD609 (32) has a very high activity of $\mathrm{IC}_{50}=0.2 \mathrm{nM}$ [8]. In 2012, NITD609 entered phase 2 clinical trials [9].

In addition to antimalarial studies, $\mathrm{TH} \beta \mathrm{Cs}$ have recently also gained attention as potential antileishmanial and trypanocidal compounds. Leishmaniasis is a tropical infectious disease and the number of people infected with leishmaniasis is $\sim 12$ million. The annual incidence of leishmaniasis is $\sim 2$ million cases and the numbers are increasing. Leishmaniasis is caused by the protozoan flagellate Leishmania spp., most notably L. donovani, which is spread by sand flies (Phlebotomus and Lutzomyia spp.). About $90 \%$ of leishmaniasis cases occur on the Indian Peninsula, in Brazil and in Sudan [54].

Trypanosoma spp. cause trypanosomiasis that can either be manifested as African trypanosomiasis (sleeping sickness) caused by $T$. brucei or as Chagas disease caused by $T$. cruzi. The incidence of African trypanosomiasis is 50,000-70,000 cases annually and it is endemic to the tropical Africa, while Chagas disease occurs in the Middle and Southern America. The approximated number of people with Chagas disease is 8-11 million [54].

It has been known for a long time that such complicated $\mathrm{TH} \beta \mathrm{C}$ alkaloids as $\alpha$-yohimbine, corynanthine and buchtienine exhibit antileishmanial activity [56,57]. However, during the last 5 years a new interest has arisen towards smaller, synthetic TH $\beta C$ derivatives and several publications have reported antileishmanial activity. In 2010, Chauhan et al. synthesized a series of indolylglyoxylamides with the general structure $\mathbf{3 3}$ and reported good antileishmanial activities with $\mathrm{IC}_{50}$ values of $3.79 \mu \mathrm{M}$ and $5.17 \mu \mathrm{M}$ for the ortho-bromosubstituted and para-ethylated compounds, respectively [58]. These values were several folds better than the standard drug activities ( $\mathrm{IC}_{50}$ of pentamidine: $20.43 \mu \mathrm{M}$ ). Kumar et al. have reported triazine derivatives $\mathbf{3 4}$ as well as other similar derivatives $\mathbf{3 5}$ as leishmanicidals $[59,60]$. The triazino derivatives have also been tested in vivo. Gellis et al. have tested their antimalarial compounds with the general structure $\mathbf{3 0}$ for antileishmanial activity. A $p$-bromosubstituted compound showed the most promising inhibitory activity towards L. Donovani, with $\mathrm{IC}_{50}$ value of $6.1 \mu \mathrm{M}$ ( $\mathrm{IC}_{50}$ of pentamidine: $\left.6.3 \mu \mathrm{M}\right)$ [5].

Some TH $\beta C$ derivatives have also been studied for trypanocidal activity. In 2010, Tonin and Valdez published studies on similar TH $\beta$ C derivatives (36 and 37) [61]. These compounds showed promising 
activity and compound $\mathbf{3 7}$ has been further studied for synergistic activity with other medication [62] but these publications remain the only publications so far on trypanocidal activity of TH $\beta \mathrm{C}$ derivatives.

\subsection{Antiviral Activity}

TH $\beta$ Cs have been recognized as antiviral compounds since 1984 when Rinehart et al. first studied eudistomins against herpes simplex virus-1 (HSV-1). Eudistomins are marine alkaloids isolated from the colonial tunicate Eudistoma olivaceum, and four eudistomins contain the TH $\beta \mathrm{C}$ scaffold (38-41, Figure 5) [10,11].

Figure 5. TH $\beta$ Cs with antiviral properties.<smiles>[R]c1cc2[nH]c3c(c2c([R])c1[R])CCN1OCSC[C@H](N)[C@H]31</smiles>

38 eudistomin $\mathrm{C} \mathrm{R}_{1}=\mathrm{H} \mathrm{R}_{2}=\mathrm{OH} \mathrm{R}=\mathrm{Br}$

39 eudistomin $\mathrm{E} \mathrm{R}_{1}=\mathrm{Br} \mathrm{R}_{2}=\mathrm{OH} \mathrm{R} \mathrm{R}_{3}=\mathrm{H}$

10 eudistomin $\mathrm{K} \mathrm{R}_{1}=\mathrm{H} \mathrm{R}_{2}=\mathrm{H} \mathrm{R}_{3}=\mathrm{Br}$

41 eudistomin $\mathrm{L} \mathrm{R}_{1}=\mathrm{H} \mathrm{R}_{2}=\mathrm{Br} \mathrm{R}_{3}=\mathrm{H}$

42 (-)-debromoeudistomin $\mathrm{K} \mathrm{R}_{1}=\mathrm{H} \mathrm{R}_{2}=\mathrm{H} \mathrm{R}_{3}=\mathrm{H}$

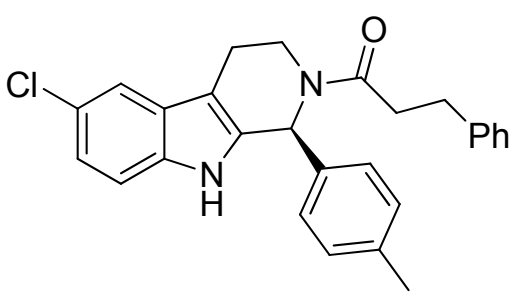

43

In addition to the basic TH $\beta \mathrm{C}$ structure, eudistomins $\mathrm{C}, \mathrm{E}, \mathrm{K}$, and $\mathrm{L}$ have a condensed oxathiazepine ring system, only reported in these compounds. It has been reported that these four eudistomins have in vitro activities against Herpes simplex virus-1 (HSV-1) ranging from 25-250 ng/12.5 mm disc [10]. Later it was also reported that eudistomin K showed activity against the polio vaccine type-1 virus [63]. Eudistomins $\mathrm{C}$ and $\mathrm{E}$ are also known to possess activities against RNA viruses such as Coxsachie A-21 virus and equine rhinovirus [11]. In 1992, (-)-debromoeudistomin K (42) and its structural analogues were tested against a number of viruses and significant antiviral activities were reported against influenza A and B in Madin-Darby canine kidney (MDCK) cells. Activities have been reported also against respiratory cyncytial virus, vesicular stomatitis virus, Coxsachie virus B4 and polio vaccine type-1 virus [12].

The antiviral activities of these eudistomins have never been further studied or developed, but a different series of TH $\beta$ Cs have been more recently studied against the human papilloma virus (HPV). In a study at GlaxoSmithKline, a series of 1-substituted TH $\beta C$ derivatives were optimized and resulted in compound $\mathbf{4 3}$ possessing nanomolar activity against HPV. The optimized compound had an activity of $\mathrm{IC}_{50}=23 \mathrm{~nm}$ [13]. GlaxoSmithKline has patented the use of this type of TH $\beta C$ s for the treatment of HPV [64].

\subsection{Anticancer}

Since the 1980s, TH $\beta C$ derivatives have been tested against cancer cell lines. During the last decade, the interest has increased tremendously as traditional TH $\beta \mathrm{C}$ targets such as the mitotic kinase Eg5 and phosphodiesterase 5 have been recognized as cancer targets. 
The first reports on the cytotoxicity of compounds with TH $\beta \mathrm{C}$ structure came in 1990 when the newly isolated eudistomins where studied for antileukemic properties. Eudistomin B (44, Figure 6) showed antitumor activity against leukemic cell lines L1210 and L5178Y [65]. Later also eudistomin $\mathrm{K}$ (40, Figure 5) was described as an antitumor lead against the murine leukemia cell line P-388, the human leukemia cell line L-1210 and human adenocarcinoma cell lines A-549 and HCT-8 [12]. Eudistomin E (39) is also active against the human mouth epidermal carcinoma KB cell line [66]. Apart from eudistomins, few $\mathrm{TH} \beta \mathrm{C}$ derivatives had been studied for antitumor properties until recent years. However, the group of TH $\beta$ Cs that are today recognized as antitumor compounds is growing.

Figure 6. TH $\beta \mathrm{Cs}$ with cytotoxicity activity.
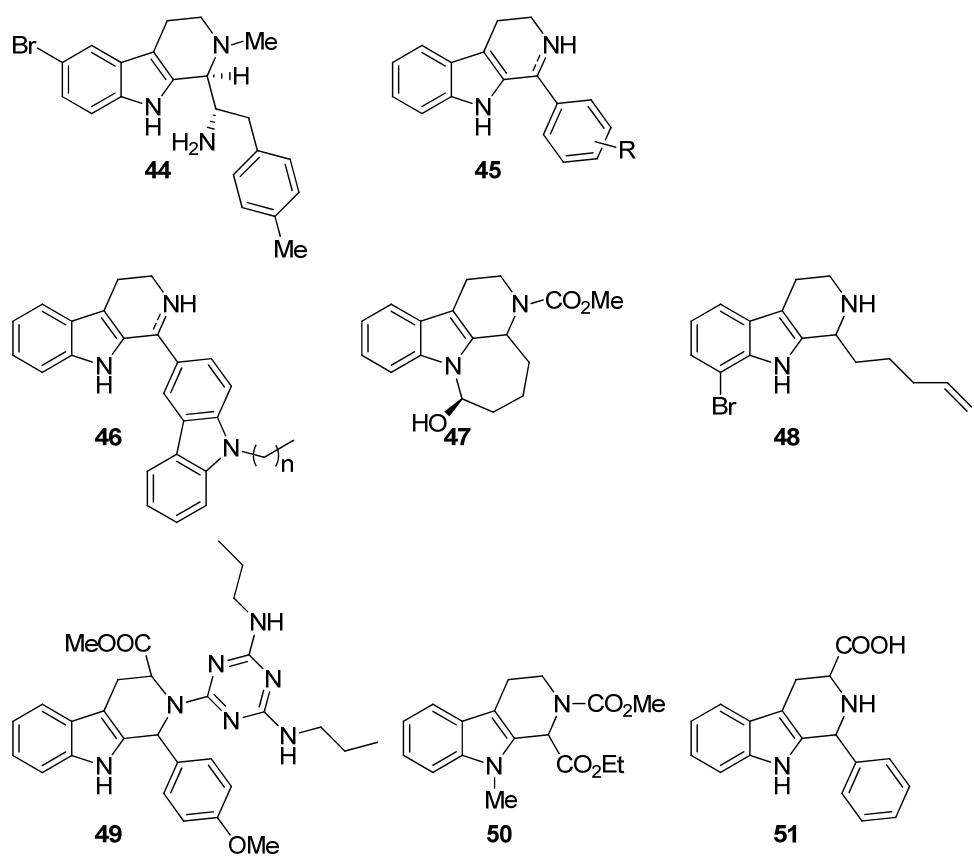

In 2005, Shen et al. synthesized a series of simple TH $\beta C$ and $\mathrm{DH} \beta \mathrm{C}$ derivatives with the general structure 45. The compounds were examined against the murine cell line P-388 and the human cell lines KB-16 and A-549, and the human colon adenocarcinoma cell line HT-29. All synthesized compounds exhibited moderate cytotoxicity [67]. In 2011, Shen et al. published a new study in which they had increased the size of the substituent in $\mathrm{C} 1$ and had a series of TH $\beta \mathrm{Cs}$ and DH $\beta C$ s with general structure 46. The series was evaluated for antitumor activity against human tumor cells including $\mathrm{KB}$, DLD, NCI-H661, Hepa, and HepG2/A2 cell lines. In this study, the DH $\beta C$ derivatives gave generally better results though also the TH $\beta$ Cs showed significant cytotoxicity [14].

In 2009, Santos et al., inspired by arborescidine alkaloids, synthesized tetracyclic compounds resembling arborescidines and tested them for antitumor activity towards human lung fibroblasts (MRC-5), human gastric adenocarcinoma (AGS), human lung cancer (SK-MES-1), human bladder carcinoma (J82) and human leukemia (HL-60) cells [68]. From the arborescidine resembling compounds, compound $\mathbf{4 7}$ showed most activity having $\mathrm{IC}_{50}$ values in micromolar range. The research group also tested all the intermediate compounds they had synthesized and found that the non-cyclic compound 48 actually gave better response to almost all tested cell lines with $\mathrm{IC}_{50}$ values ranging from 8.8 to $18.1 \mu \mathrm{M}$ for lung fibroblasts, gastric adenocarcinoma, lung cancer and bladder carcinoma $\left(\mathrm{IC}_{50}\right.$ 
of standard etoposide: $0.36-3.93 \mu \mathrm{M}$ ). Kumar et al. have also tested their leishmanicidal triazine TH $\beta C$ hybrids (34, Figure 4) for cytotoxicity and found that they display nanomolar cytotoxic activity. Their best hit was compound 49, which had an $\mathrm{IC}_{50}$ value of $122 \mathrm{nM}$ [69]. In 2012, Skouta et al. synthesized a series of 1,2-disubstituted TH $\beta$ Cs and found that compound $\mathbf{5 0}$ showed a unique selectivity towards tumorigenic versus non-tumorigenic cells and induced cell death without the activation of caspases, hence inducing a non-apoptotic cell death [15]. Simple 1,3-disubstituted TH $\beta \mathrm{Cs}$ have also been tested for cytotoxic activity against the insect origin Spodoptera frugiperda $\mathrm{Sf} 9$ cell line and the most promising compound was 1-phenyl-TH $\beta \mathrm{C}-3$-carboxylic acid (51). Furthermore, these compounds experienced substantial insecticidal activity against mosquito larvae of Culex pipiens quinquefasciatus species and mustard aphid (Lipaphis erysimi) [70].

Today, one very interesting feature in TH $\beta C$ s is their recognition as mitotic kinesin spindle protein (KSP, also referred to as Eg5) inhibitors. Mitosis is the part of cell division in which the chromosomes condense and divide into two identical sets. The mitotic kinesins are intimately involved in the formation of the mitotic spindle, chromosome segregation, checkpoint control and cytokinesis (Figure 7). The kinesin spindle proteins are highly expressed in breast, ovary, colon, lung, uterine and retinoblastoma tumors [71].

Figure 7. Mitosis and the mitotic kinesins involved in the five steps [72].

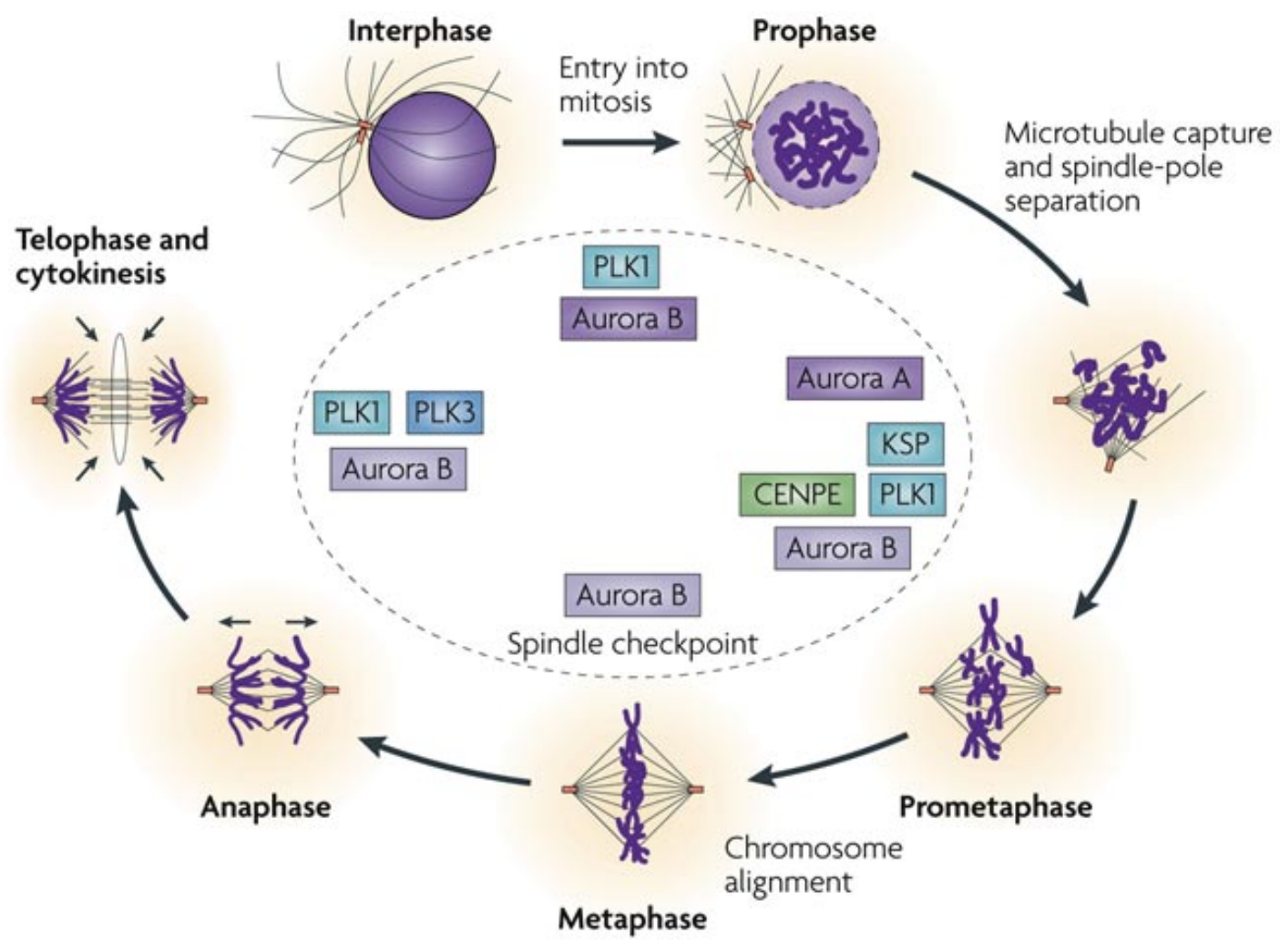

Nature Reviews | Cancer

KSPs became an important cancer target when monastrol, the first KSP inhibitor, was discovered in 1999. During the last decade, the development of KSP inhibitors has been rapid and many pharmaceutical companies now have KSP inhibitor drugs in clinical trials [71]. During the last ten 
years, several papers have been published on the KSP inhibitory properties of TH $\beta \mathrm{C}$ derivatives (Figure 8) [16,73-78]. The mitotic kinesin spindle proteins as cancer targets have been the subject of several recent reviews such as the extensive reviews by Schmidt and Bastians in 2007 [79] and Chan et al. in 2012 [80].

Figure 8. Mitotic kinesin spindle protein (KSP) inhibitors.
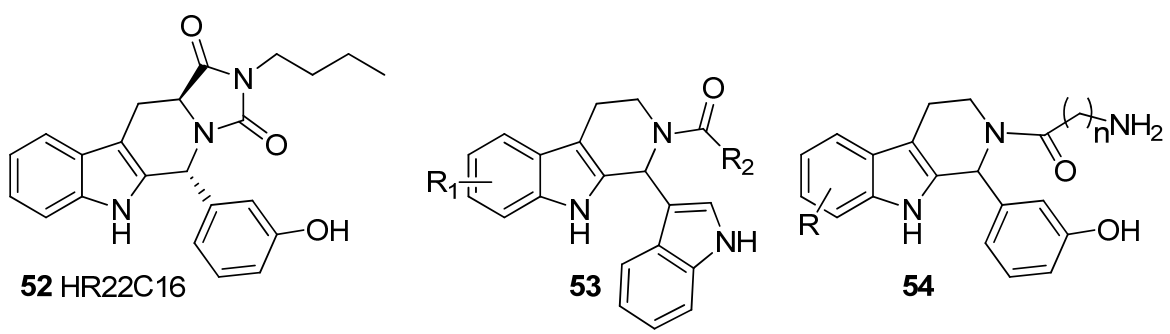

In 2003 Hotha et al. published the results of an extensive screening that revealed a TH $\beta \mathrm{C}$ derivative HR22C16 (52) as a potential lead compound for KSP inhibition. They reported that HR22C16 had an $\mathrm{IC}_{50}$ value of $800 \mathrm{nM}$ against KSP [16]. After the discovery of HR22C16, several related derivatives and their inhibitory actions have been reported. In 2005, Sunder-Plassmann et al. published a series of HR22C16 derivatives and reported that replacing the N-butyl side chain with an N-benzyl side chain increases inhibitory activity to $\mathrm{IC}_{50}=650 \mathrm{nM}$ [73]. These type of indolopyridines were patented in 2009 as KSP inhibitors by a German pharmaceutical company, 4SC [74]. The company has now one KSP inhibitor in clinical Phase I trials (SC4-205) [75] and although its structure is not yet revealed, it was speculated in a recent review that it is based on the indolopyridine scaffold [76].

HR22C16 inspired compounds have also been further studied by Liu et al. who reported that the metabolically liable phenol group can be replaced with indolyl without losing inhibitory activity [77]. The research group also replaced the fourth ring in the HR22C16 structure with a simple acyl group on $\mathrm{N} 2$ giving compounds of general structure 53, thus returning to the original TH $\beta \mathrm{C}$ three-ring system. Barsanti et al. also published a paper in which 1,2-disubstituted TH $\beta$ Cs 54 were evaluated as KSP inhibitors [78]. The structures of Barsanti's compounds 54 and Liu's compounds 53 are highly similar. Barsanti's most promising lead had an $\mathrm{IC}_{50}$ value of $58 \mathrm{nM}$. The group was also able to co-crystallize the inhibitor with KSP making it possible to observe the major interactions in the binding site of KSP with their ligand (Figure 9).

A novel application for TH $\beta$ Cs arose when phosphodiesterase 5 (PDE5) became a promising cancer treatment target. Phosphodiesterases are enzymes that catalyze the breakdown of cyclic guanosine monophosphate (cGMP) to guanosine monophosphate (GMP). PDE5 inhibition is one of the common targets for compounds with the TH $\beta \mathrm{C}$ structure. It has traditionally been a target for treating erectile dysfunction and pulmonary arterial hypertension. Increased concentration of cGMP in vascular smooth muscle cells leads to vasodilation and subsequently erection. In 2006, Serafini et al. first recognized PDE5 inhibitors as antitumor agents [17]. The use of PDE5 inhibitors in the treatment of cancer was reviewed in 2009 [81].

As tadalafil (Figure 2) was one of the PDE5 inhibitors Serafini et al. used when testing antitumor properties, it is not surprising that many papers discuss the cytotoxicity of tadalafil-inspired compounds. Tadalafil acts as a PDE5 inhibitor in low nanomolar range and analogues with similar $\mathrm{IC}_{50}$ 
values have been synthesized [82-85]. The generalized Markush structure 55 (Figure 10) and its use as a PDE5 inhibitor was patented in 2011 [86].

Figure 9. Schematic presentation of interactions between the ATP binding pocket of KSP and inhibitor [78].

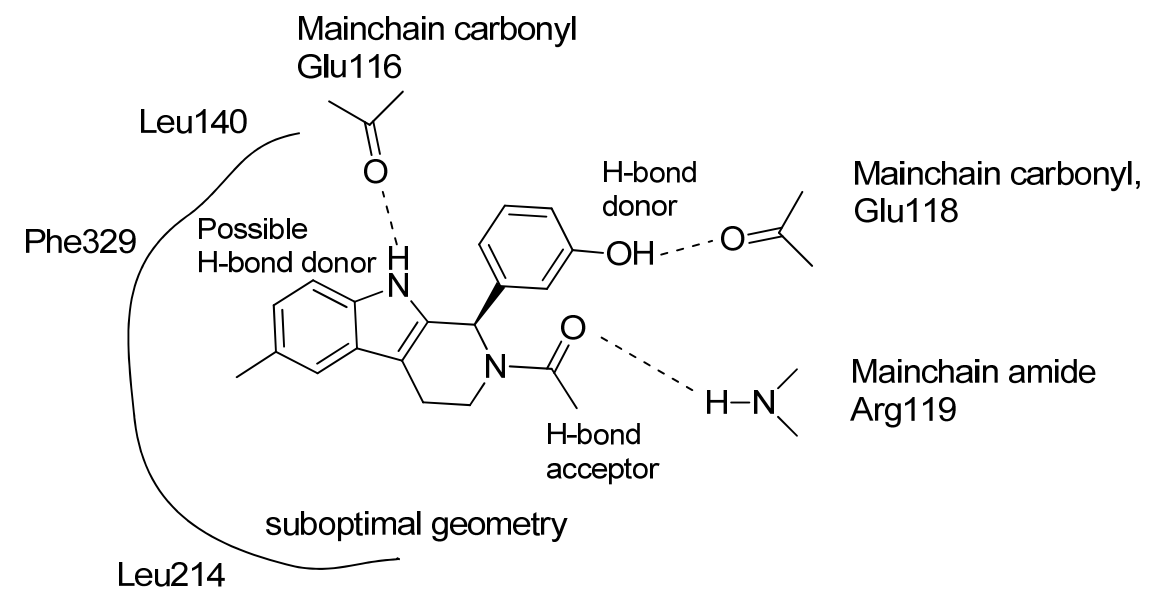

Figure 10. PDE5 inhibitor.<smiles>[R]c1ccc(C2c3[nH]c4ccccc4c3CC(C([R6])[R])N2[R])cc1[R]</smiles>

\subsection{Other Pharmacological Uses}

Complex natural alkaloids that contain the TH $\beta \mathrm{C}$ structure such as yohimbine or reserpine have a wide range of pharmacological activities. The extracts from Rauwolfia spp. has been a part of traditional medicine in tropical and subtropical areas. Some known mechanisms of action of this type of molecules are serotonin receptor (5HT) antagonism and $\alpha$-adrenergic receptor antagonism. Hence these molecules have a profound effect on the CNS, being hallucinogens, vasodilators and analgesics. However, as the range of activities is broad and these compounds lack inherent selectivity, they haven't been very useful in modern medicine [87].

Serotonin receptor antagonism has been studied with simple TH $\beta C$ s. An example of such a study was done in the Lilly research laboratories in 1996 by Audia et al. who synthetized a series of 1 -substituted TH $\beta$ Cs in which the substituent consisted of various benzyl or naphthyl groups, as in compound 56 (Figure 11) [88]. The compounds showed moderate selective antagonism towards the $5 \mathrm{HT}_{2 \mathrm{~B}}-$ receptor. Similar studies were conducted by Giorgioni et al. in 2005 [89]. No recent studies have been published on TH $\beta \mathrm{Cs}$ as $5 \mathrm{HT}$ antagonists.

During the last decade, several novel receptor interactions and possible applications of TH $\beta \mathrm{C}$ derived compounds have been suggested. Glennon et al. has reported the binding of simple 
C1-unsubstituted TH $\beta$ Cs 57 to imidazole receptors $I_{2}$ and $I_{3}$ [90]. In 2001, Poitout et al. first described 1,3-substituted TH $\beta$ C derivatives $\mathbf{5 8}$ as selective somatostatin receptor type 3 (SSTR3) antagonists [91,92]. Somatostatin receptors are G-protein coupled receptors inhibiting adenylyl cyclase, thus exerting various other effects on intracellular messenger systems. SSTRs are known to mediate cognitive effects, growth hormone inhibition and insulin secretion inhibition [93]. Merck and Co have been granted a patent in the use of TH $\beta C$ based compounds similar to $\mathbf{5 8}$ as SSTR3 antagonists in the treatment of type 2 diabetes mellitus [94].

Figure 11. TH $\beta C$ derivatives with miscellaneous pharmacological activities.
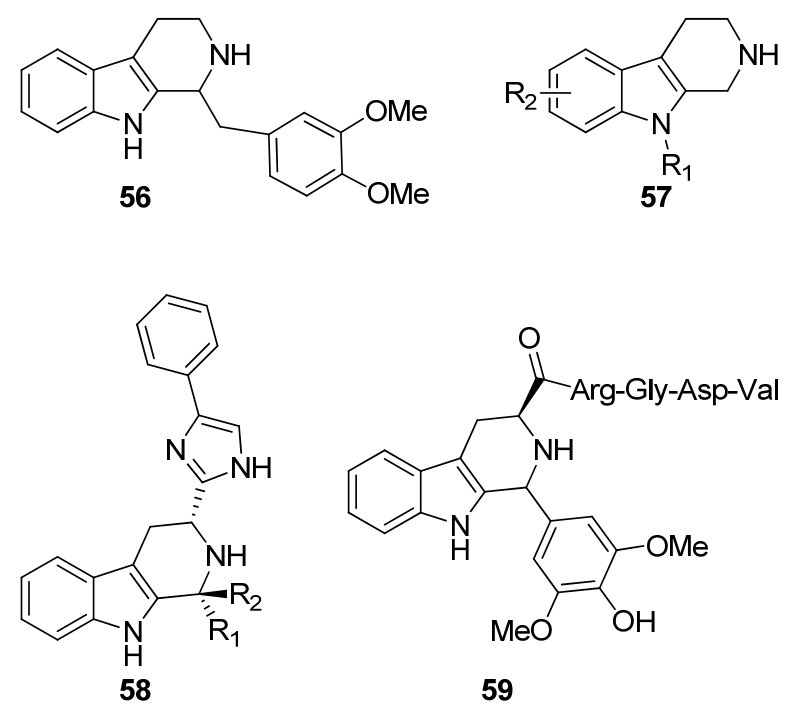

TH $\beta C$ derivatives have also been patented for several other uses: protein tyrosine phosphatase (PTP) inhibition [95], growth hormone secretagogue receptor (GHSR) antagonism [96] and histamine receptor modulation [97]. In 2013, TH $\beta$ C derivatives were reported to target fatty acid amide hydrolase (FAAH) and transient receptor potential (TRP) channels [98]. Furthermore, two publications have suggested that TH $\beta$ C RGD peptidomimetic conjugate $\mathbf{5 9}$ acts as an antithrombotic agents and have free radical scavenging properties $[99,100]$.

\section{Conclusions}

This review illustrates the pharmacological importance of C1-substituted optically active TH $\beta \mathrm{Cs}$ featuring numerous recent studies. Development has been rapid especially in antitumor applications as well as in antimalarial applications. Moreover, several novel targets have been recently recognized. Although methods to establish the $\mathrm{C} 1$ stereocenter exist, there is room for development and additional contributions.

\section{Acknowledgments}

Financial support from the Tekniikan Edistämissäätiö (TES) is gratefully acknowledged. 


\section{Author Contributions}

A.E.L designed and conducted the study. A.E.L. wrote the manuscript and C.L. and A.M.P.K. critically revised it and gave scientific advisory.

\section{Conflicts of Interest}

The authors declare no conflict of interest.

\section{References and Notes}

1. Hesse, M. Alkaloids: Nature's Curse or Blessing; Wiley-VCH: Zürich, Switzerland, 2002; pp. 14-27.

2. Daugan, A.; Grondin, P.; Ruault, C.; le Monnier, D.G.; Coste, H.; Kirilovsky, J.; Hyafil, F.; Labaudiniere, R. The discovery of tadalafil: A novel and highly selective PDE5 inhibitor. 1: 5,6,11,11a-Tetrahydro-1H-imidazo[1',5':1,6]pyrido[3,4-B]indole-1,3(2H)-dione analogues. J. Med. Chem. 2003, 46, 4525-4532.

3. Davis, R.A.; Duffy, S.; Avery, V.M.; Camp, D.; Hooper, J.N.A.; Quinn, R.J. (+)-7Bromotrypargine: An Antimalarial $\beta$-Carboline from the Australian Marine Sponge Ancorina Sp. Tetrahedron Lett. 2010, 51, 583-585.

4. Chan, S.T.S.; Pearce, A.N.; Page, M.J.; Kaiser, M.; Copp, B.R. Antimalarial $\beta$-Carbolines from the New Zealand Ascidian Pseudodistoma opacum. J. Nat. Prod. 2011, 74, 1972-1979.

5. Gellis, A.; Dumètre, A.; Lanzada, G.; Hutter, S.; Ollivier, E.; Vanelle, P.; Azas, N. Preparation and antiprotozoal evaluation of promising $\beta$-carboline alkaloids. Biomed. Pharmacother. 2012, 66, 339-347.

6. Gupta, L.; Srivastava, K.; Singh, S.; Puri, S.K.; Chauhan, P.M.S. Synthesis of 2-[3-(7-ChloroQuinolin-4-ylamino)-Alkyl]-1-(Substituted Phenyl)-2,3,4,9-Tetrahydro-1H- $\beta$-Carbolines as a New Class of Antimalarial Agents. Bioorg. Med. Chem. Lett. 2008, 18, 3306-3309.

7. Rottmann, M.; McNamara, C.; Yeung, B.K.S.; Lee, M.C.S.; Zou, B.; Russell, B.; Seitz, P.; Plouffe, D.M.; Dharia, N.V.; Tan, J.; et al. Spiroindolones, a potent compound class for the treatment of malaria. Science 2010, 329, 1175-1180.

8. Yeung, B.K.S.; Zou, B.; Rottmann, M.; Lakshminarayana, S.B.; Ang, S.H.; Leong, S.Y.; Tan, J.; Wong, J.; Keller-Maerki, S.; Fischli, C.; et al. Spirotetrahydro $\beta$-carbolines (spiroindolones): A new class of potent and orally efficacious compounds for the treatment of Malaria. J. Med. Chem. 2010, 53, 5155-5164.

9. IFPMA Developing World Health Partnerships: Novartis R\&D for Malaria. Available online: http://partnerships.ifpma.org/partnership/novartis-r-d-for-malaria (accessed on 23 July 2013).

10. Rinehart, K.L.; Kobayashi, J.; Harbour, G.C.; Hughes, R.G.; Mizsak, S.A.; Scahill, T.A. Eudistomins C, E, K, and L, potent antiviral compounds containing a novel oxathiazepine ring from the caribbean tunicate Eudistoma olivaceum. J. Am. Chem. Soc. 1984, 106, 1524-1526.

11. Rinehart, K.L.; Kobayashi, J.; Harbour, G.C.; Gilmore, J.; Mascal, M.; Holt, T.G.; Shield, L.S.; Lafargue, F. Eudistomins A-Q, $\beta$-Carbolines from the Antiviral Caribbean Tunicate Eudistoma. olivaceum. J. Am. Chem. Soc. 1987, 109, 3378-3387. 
12. Van Maarseveen, J.H.; Hermkens, P.H.H.; de Clercq, E.; Balzarini, J.; Scheeren, H.W.; Kruse, C.G. Antiviral and antitumor structure-activity relationship studies on tetracyclic eudistomines. J. Med. Chem. 1992, 35, 3223-3230.

13. Miller, J.F.; Turner, E.M.; Sherrill, R.G.; Gudmundsson, K.; Spaltenstein, A.; Sethna, P.; Brown, K.W.; Harvey, R.; Romines, K.R.; Golden, P. Substituted tetrahydro- $\beta$-carbolines as potential agents for the treatment of human papillomavirus infection. Bioorg. Med. Chem. Lett. 2010, 20, 256-259.

14. Shen, Y.; Chang, Y.; Lin, C.; Liaw, C.; Kuo, Y.H.; Tu, L.; Yeh, S.F.; Chern, J. Synthesis of 1-substituted carbazolyl-1,2,3,4-tetrahydro- and carbazolyl-3,4-dihydro- $\hat{1}^{2}$-carboline analogs as potential antitumor agents. Mar. Drugs 2011, 9, 256-277.

15. Skouta, R.; Hayano, M.; Shimada, K.; Stockwell, B.R. Design and synthesis of pictet-spengler condensation products that exhibit oncogenic-ras synthetic lethality and induce non-apoptotic cell death. Bioorg. Med. Chem. Lett. 2012, 22, 5707-5713.

16. Hotha, S.; Yarrow, J.C.; Yang, J.G.; Garrett, S.; Renduchintala, K.V.; Mayer, T.U.; Kapoor, T.M. HR22C16: A potent small-molecule probe for the dynamics of cell division. Angew. Chem. 2003, 115, 2481-2484.

17. Serafini, P.; Meckel, K.; Kelso, M.; Noonan, K.; Califano, J.; Koch, W.; Dolcetti, L.; Bronte, V.; Borrello, I. Phosphodiesterase-5 inhibition augments endogenous antitumor immunity by reducing myeloid-derived suppressor cell function. J. Exp. Med. 2006, 203, 2691-2702.

18. Cao, R.; Peng, W.; Wang, Z.; Xu, A. Carboline alkaloids: Biochemical and pharmacological functions. Curr. Med. Chem. 2007, 14, 479-500.

19. Allen, J.R.F.; Holmstedt, B.R. The simple $\beta$-carboline alkaloids. Phytochemistry 1980, 19, $1573-1582$.

20. Goebel, F. Über das Harmalin. Justus Liebigs. Ann. Chem. 1841, 38, 363-366. (in German).

21. Sumpter, W.C.; Miller, F.M. Heterocyclic Compounds with Indole and Carbazole Systems; Wiley Interscience: New York, NY, USA, 1954.

22. Maresh, J.J.; Giddings, L.; Friedrich, A.; Loris, E.A.; Panjikar, S.; Trout, B.L.; Stöckigt, J.; Peters, B.; O'Connor, S.E. Strictosidine synthase: Mechanism of a pictet-spengler catalyzing enzyme. J. Am. Chem. Soc. 2008, 130, 710-723.

23. Stöckigt, J.; Antonchick, A.P.; Wu, F.; Waldmann, H. The pictet-spengler reaction in nature and in organic chemistry. Angew. Chem. Int. Ed. 2011, 50, 8538-8564.

24. Pictet, A.; Spengler, T. Über die bildung von isochinolin-derivaten durch einwirkung von methylal auf phenyl-äthylamin, phenyl-alanin und tyrosin. Ber. Deutsch. Chem. Gesell. 1911, 44, 2030-2036. (in German).

25. Cox, E.D.; Cook, J.M. The pictet-spengler condensation: A new direction for an old reaction. Chem. Rev. 1995, 95, 1797-1842.

26. Bischler, A.; Napieralski, B. Zur kenntniss einer neuen isochinolinsynthese. Ber. Deutsch. Chem. Gesell. 1893, 26, 1903-1908. (in German).

27. Uematsu, N.; Fujii, A.; Hashiguchi, S.; Ikariya, T.; Noyori, R. Asymmetric transfer hydrogenation of imines. J. Am. Chem. Soc. 1996, 118, 4916-4917.

28. Woodward, R.B.; Bader, F.E.; Bickel, H.; Frey, A.J.; Kierstead, R.W. The total synthesis of reserpine. Tetrahedron 1958, 2, 1-57. 
29. Bailey, P.D.; Cochrane, P.J.; Lorenz, K.; Collier, I.D.; Pearson, D.P.J.; Rosair, G.M. A concise, efficient route to fumitremorgins. Tetrahedron Lett. 2001, 42, 113-115.

30. Koskinen, A.M.P. Asymmetric Synthesis of Natural Products, 2nd ed.; John Wiley \& Sons: Chichester, UK, 2012; pp. 259-261.

31. Bailey, P.D.; Hollinshead, S.P.; McLay, N.R.; Morgan, K.; Palmer, S.J.; Prince, S.N.; Reynolds, C.D.; Wood, S.D. Diastereo- and enantio-selectivity in the pictet-spengler reaction. J. Chem. Soc. Perkin Trans. 1 1993, 4, 431-439.

32. Ardeo, A.; García, E.; Arrasate, S.; Lete, E.; Sotomayor, N. A practical approach to the fused $\beta$-carboline system. asymmetric synthesis of indolo[2,3-a]indolizidinones via a diastereoselective intramolecular $\alpha$-amidoalkylation reaction. Tetrahedron Lett. 2003, 44, 8445-8448.

33. Li, J.; Wang, T.; Yu, P.; Peterson, A.; Weber, R.; Soerens, D.; Grubisha, D.; Bennett, D.; Cook, J.M. General approach for the synthesis of ajmaline/sarpagine indole alkaloids: Enantiospecific total synthesis of (+)-ajmaline, alkaloid $\mathrm{g}$, and norsuaveoline via the asymmetric pictet-spengler reaction. J. Am. Chem. Soc. 1999, 121, 6998-7010.

34. Liu, X.; Deschamp, J.R.; Cook, J.M. Regiospecific, enantiospecific total synthesis of the alkoxy-substituted indole bases, 16-epi- $\mathrm{n}_{\mathrm{a}}$-methylgardneral, 11-methoxyaffinisine, and 11-methoxymacroline as well as the indole alkaloids alstophylline and macralstonine. Org. Lett. 2002, 4, 3339-3342.

35. Bailey, P.D.; Clingan, P.D.; Mills, T.J.; Price, R.A.; Pritchard, R.G. Total synthesis of (-)-raumacline. Chem. Commun. 2003, 22, 2800-2801.

36. Alberch, L.; Bailey, P.D.; Clingan, P.D.; Mills, T.J.; Price, R.A.; Pritchard, R.G. The cis-specific pictet-spengler reaction. Eur. J. Org. Chem. 2004, 2004, 1887-1890.

37. Bailey, P.D.; Beard, M.A.; Phillips, T.R. Unexpected cis selectivity in the pictet-spengler reaction. Tetrahedron Lett. 2009, 50, 3645-3647.

38. Yamada, H.; Kawate, T.; Nishida, A.; Nakagawa, M. Asymmetric addition of alkyllithium to chiral imines: $\alpha$-naphthylethyl group as a chiral auxiliary. J. Org. Chem. 1999, 64, 8821-8828.

39. Soe, T.; Kawate, T.; Fukui, N.; Nakagawa, M. Asymmetric pictet-spengler reaction with chiral-n-( $\beta$-3-indolyl)ethyl-1-methylbenzylamine. Tetrahedron Lett. 1995, 36, 1857-1860.

40. Waldmann, H.; Schmidt, G.; Henke, H.; Burkard, M. Asymmetric pictet-spengler reactions employing n,n-phthaloyl amino acids as chiral auxiliary groups. Angew. Chem. Int. Ed. Engl. 1995, 34, 2402-2403.

41. Ducrot, P.; Rabhi, C.; Thal, C. Synthesis of tetrahydro- $\beta$-carbolines and studies of the pictet-spengler reaction. Tetrahedron 2000, 56, 2683-2692.

42. Kawate, T.; Yamada, H.; Soe, T.; Nakagawa, M. Enantioselective asymmetric pictet-spengler reaction catalyzed by diisopinocampheylchloroborane. Tetrahedron Asymmetry 1996, 7, 1249-1252.

43. Raheem, I.T.; Thiara, P.S.; Peterson, E.A.; Jacobsen, E.N. Enantioselective pictet-spengler-type cyclizations of hydroxylactams: H-bond donor catalysis by anion binding. J. Am. Chem. Soc. 2007, 129, 13404-13405.

44. Klausen, R.S.; Jacobsen, E.N. Weak bronsted acid thiourea co-catalysis: Enantioselective, catalytic protio-pictet-spengler reactions. Org. Lett. 2009, 11, 887-890.

45. Seayad, J.; Seayad, A.M.; List, B. Catalytic asymmetric pictet-spengler reaction. J. Am. Chem. Soc. 2006, 128, 1086-1087. 
46. Wanner, M.J.; van der Haas, R.N.S.; de Cuba, K.R.; van Maarseveen, J.H.; Hiemstra, H. Catalytic asymmetric pictet-spengler reactions via sulfenyliminium ions. Angew. Chem. 2007, 119, 7629-7631.

47. Priebbenow, D.L.; Henderson, L.C.; Pfeffer, F.M.; Stewart, S.G. Domino Heck-aza-Michael reactions: Efficient access to 1-substituted tetrahydro- $\beta$-carbolines. J. Org. Chem. 2010, 75, 1787-1790.

48. Rixson, J.E.; Chaloner, T.; Heath, C.H.; Tietze, L.F.; Stewart, S.G. The development of Domino reactions incorporating the Heck reaction: The formation of N-heterocycles. Eur. J. Org. Chem. 2012, 2012, 544-558.

49. Priebbenow, D.L.; Stewart, S.G.; Pfeffer, F.M. Asymmetric induction in domino heck-aza-michael reactions. Tetrahedron Lett. 2012, 53, 1468-1471.

50. Meyers, A.I.; Sohda, T.; Loewe, M.F. An asymmetric synthesis and absolute configuration of (S)(-)-deplancheine. J. Org. Chem. 1986, 51, 3108-3112.

51. Meyers, A.I.; Miller, D.B.; White, F.H. Chiral and achiral formamidines in synthesis. The first asymmetric route to (-)-yohimbine and an efficient total synthesis of ( \pm )-yohimbine. $J . A m$. Chem. Soc. 1988, 110, 4778-4787.

52. Gul, W.; Hamann, M.T. Indole alkaloid marine natural products: An established source of cancer drug leads with considerable promise for the control of parasitic, neurological and other diseases. Life Sci. 2005, 78, 442-453.

53. World Malaria Report 2012. Available online: http://www.who.int/malaria/publications/ world_malaria_report_2012/report/en/index.html (accessed on 23 July 2013).

54. Kaufman, T.S.; Rúveda, E.A. The quest for quinine: Those who won the battles and those won the war. Angew. Chem. Int. Ed. 2005, 44, 854-885.

55. Sidhu, A.B.S.; Verdier-Pinard, D.; Fidock, D.A. Chloroquine resistance in Plasmodium falciparum malaria parasites conferred by Pfcrt mutations. Science 2002, 298, 210-213.

56. Staerk, D.; Lemmich, E.; Christensen, J.; Kharazmi, A.; Olsen, C.E.; Jaroszewski, J.W. Leishmanicidal, Antiplasmodial and cytotoxic activity of indole alkaloids from Corynanthe. pachyceras. Planta Med. 2000, 66, 531-536.

57. Kam, T.; Sim, K.; Koyano, T.; Komiyama, K. Leishmanicidal alkaloids from Kopsia. griffithii. Phytochemistry 1999, 50, 75-79.

58. Chauhan, S.S.; Gupta, L.; Mittal, M.; Vishwakarma, P.; Gupta, S.; Chauhan, P.M.S. Synthesis and Biological evaluation of indolyl glyoxylamides as a new class of antileishmanial agents. Bioorg. Med. Chem. Lett. 2010, 20, 6191-6194.

59. Kumar, A.; Katiyar, S.B.; Gupta, S.; Chauhan, P.M.S. Syntheses of new substituted triazino tetrahydroisoquinolines and $\beta$-carbolines as novel antileishmanial agents. Eur. J. Med. Chem. 2006, 41, 106-113.

60. Kumar, R.; Khan, S.; Verma, A.; Srivastava, S.; Viswakarma, P.; Gupta, S.; Meena, S.; Singh, N.; Sarkar, J.; Chauhan, P.M.S. Synthesis of 2-(Pyrimidin-2-yl)-1-phenyl-2,3,4,9-tetrahydro-1H- $\beta$ carbolines as antileishmanial agents. Eur. J. Med. Chem. 2010, 45, 3274-3280.

61. Düsman Tonin, L.T.; Barbosa, V.A.; Bocca, C.C.; Ramos, É.R.F.; Nakamura, C.V.; Ferreira da Costa, W.; Basso, E.A.; Nakamura, T.U.; Sarragiotto, M.H. Comparative study of the trypanocidal activity of the methyl 1-nitrophenyl-1,2,3,4-9H-tetrahydro- $\beta$-carboline-3- 
carboxylate derivatives and benznidazole using theoretical calculations and cyclic voltammetry. Eur. J. Med. Chem. 2009, 44, 1745-1750.

62. Valdez, R.H.; Tonin, L.T.D.; Ueda-Nakamura, T.; Silva, S.O.; Dias Filho, B.P.; Kaneshima, E.N.; Yamada-Ogatta, S.F.; Yamauchi, L.M.; Sarragiotto, M.H.; Nakamura, C.V. In Vitro and in vivo Trypanocidal synergistic activity of n-butyl-1-(4-dimethylamino)phenyl-1,2,3,4-tetrahydro- $\beta$ carboline-3-carboxamide associated with benznidazole. Antimicrob. Agent. Chemother. 2012, 56, $507-512$.

63. Lake, R.J.; Blunt, J.W.; Munro, M. Eudistomins from the New Zealand ascidian Ritterella. sigillinoides. Aust. J. Chem. 1989, 42, 1201-1206.

64. Gudmundsson, K.; Miller, J.F.; Sherrill, R.G.; Turner, E.M. Useful Compounds for HPV Infection. WO2006015035A1, 9 February 2006.

65. Kobayashi, J.; Cheng, J.F.; Ohta, T.; Nozoe, S.; Ohizumi, Y.; Sasaki, T. Eudistomidins B, C, and D: Novel antileukemic alkaloids from the okinawan marine tunicate Eudistoma glaucus. J. Org. Chem. 1990, 55, 3666-3670.

66. Adesanya, S.A.; Chbani, M.; Paîs, M.; Debitus, C. Brominated beta-carbolines from the marine tunicate Eudistoma album. J. Nat. Prod. 1992, 55, 525-527.

67. Shen, Y.; Chen, Y.; Hsieh, P.; Duh, C.; Lin, Y.; Ko, C. The preparation and evaluation of 1 -substituted 1,2,3,4-tetrahydro- and 3,4-dihydro- $\beta$-carboline derivatives as potential antitumor agents. Chem. Pharm. Bull. 2005, 53, 32-36.

68. Santos, L.S.; Theoduloz, C.; Pilli, R.A.; Rodriguez, J. Antiproliferative activity of arborescidine alkaloids and derivatives. Eur. J. Med. Chem. 2009, 44, 3810-3815.

69. Kumar, R.; Gupta, L.; Pal, P.; Khan, S.; Singh, N.; Katiyar, S.B.; Meena, S.; Sarkar, J.; Sinha, S.; Kanaujiya, J.K.; et al. Synthesis and cytotoxicity evaluation of (tetrahydro- $\beta$-carboline)-1,3,5triazine hybrids as anticancer agents. Eur. J. Med. Chem. 2010, 45, 2265-2276.

70. Zeng, Y.; Zhang, Y.; Weng, Q.; Hu, M.; Zhong, G. Cytotoxic and insecticidal activities of derivatives of harmine, a natural insecticidal component isolated from Peganum harmala. Molecules 2010, 15, 7775-7791.

71. Sarli, V.; Giannis, A. Targeting the kinesin spindle protein: Basic principles and clinical implications. Clin. Cancer Res. 2008, 14, 7583-7587.

72. Jackson, J.R.; Patrick, D.R.; Dar, M.M.; Huang, P.S. Targeted anti-mitotic therapies: Can we improve on tubulin agents? Nat. Rev. Cancer 2007, 7, 107-117.

73. Sunder-Plassmann, N.; Sarli, V.; Gartner, M.; Utz, M.; Seiler, J.; Huemmer, S.; Mayer, T.U.; Surrey, T.; Giannis, A. Synthesis and biological evaluation of new tetrahydro- $\beta$-carbolines as inhibitors of the mitotic kinesin eg5. Bioorg. Med. Chem. 2005, 13, 6094-6111.

74. Vennemann, M.; Braunger, J.; Gimmnich, P.; Baer, T. Indolopyridines as Inhibitors of the Kinesin Spindle Protein (Eg5). WO2009024190 (A1), 25 February 2009.

75. 4SC: Product pipeline/SC4-205. Available online: http://www.4sc.de/product-pipeline/clinical/ 4SC-205 (accessed on 24 July 2013).

76. Rath, O.; Kozielski, F. Kinesins and cancer. Nat. Rev. Cancer 2012, 12, 527-539.

77. Liu, F.; Yu, L.; Jiang, C.; Yang, L.; Wu, W.; You, Q. Discovery of Tetrahydro-B-Carbolines as Inhibitors of the Mitotic Kinesin KSP. Bioorg. Med. Chem. 2010, 18, 4167-4177. 
78. Barsanti, P.A.; Wang, W.; Ni, Z.; Duhl, D.; Brammeier, N.; Martin, E.; Bussiere, D.; Walter, A.O. The discovery of tetrahydro- $\beta$-carbolines as inhibitors of the kinesin Eg5. Bioorg. Med. Chem. Lett. 2010, 20, 157-160.

79. Schmidt, M.; Bastians, H. Mitotic drug targets and the development of novel anti-mitotic anticancer drugs. Drug Resist. Updat. 2007, 10, 162-181.

80. Chan, K.; Koh, C.; Li, H. Mitosis-targeted anti-cancer therapies: Where they stand. Cell. Death Dis. 2012, 3, e411.

81. Sandeep, G.; Bhasker, S.; Ranganath, Y.S. Phosphodiesterase as a novel target in cancer chemotherapy. Internet J. Pharmacol. 2009, 7, 1.

82. El-Gamil, D.S.; Ahmed, N.S.; Gary, B.D.; Piazza, G.A.; Engel, M.; Hartmann, R.W.; Abadi, A.H. Design of novel $\beta$-carboline derivatives with pendant 5-bromothienyl and their evaluation as phosphodiesterase-5 inhibitors. Arch. Pharm. 2013, 346, 23-33.

83. Abadi, A.H.; Lehmann, J.; Piazza, G.A.; Abdel-Halim, M.; Ali, M.S.M. Synthesis, molecular modeling, and biological evaluation of novel tetrahydro- $\beta$-carboline hydantoin and tetrahydro- $\beta$ carboline thiohydantoin derivatives as phosphodiesterase 5 inhibitors. Int. J. Med. Chem. 2011, 2011, doi:org/10.1155/2011/562421.

84. Mohamed, H.A.; Girgis, N.M.R.; Wilcken, R.; Bauer, M.R.; Tinsley, H.N.; Gary, B.D.; Piazza, G.A.; Boeckler, F.M.; Abadi, A.H. Synthesis and molecular modeling of novel tetrahydro- $\beta$-carboline derivatives with phosphodiesterase 5 inhibitory and anticancer properties. J. Med. Chem. 2011, 54, 495-509.

85. Ahmed, N.S.; Gary, B.D.; Tinsley, H.N.; Piazza, G.A.; Laufer, S.; Abadi, A.H. Design, synthesis and structure-activity relationship of functionalized tetrahydro- $\beta$-carboline derivatives as novel PDE5 inhibitors. Arch. Pharm. 2011, 344, 149-157.

86. Abadi, A.H.; Piazza, G. Tetrahydro- $\beta$-Carboline Derivatives, Synthesis and Use Thereof. WO2011063223(A1), 26 May 2011.

87. Saxton, J.E. Monoterpenoid Indole Alkaloids: Supplement to Part. 4.; Wiley: Chichester, UK, 1994; pp. 162-176, 719-725.

88. Audia, J.E.; Evrard, D.A.; Murdoch, G.R.; Droste, J.J.; Nissen, J.S.; Schenck, K.W.; Fludzinski, P.; Lucaites, V.L.; Nelson, D.L.; Cohen, M.L. Potent, selective tetrahydro- $\beta$-carboline antagonists of the serotonin 2B (5HT2B) contractile receptor in the rat stomach fundus. J. Med. Chem. 1996, $39,2773-2780$.

89. Giorgioni, G.; Accorroni, B.; Stefano, A.; Marucci, G.; Siniscalchi, A.; Claudi, F. Benzimidazole, Benzoxazole and benzothiazole derivatives as $5 \mathrm{ht} 2 \mathrm{~b}$ receptor ligands. synthesis and preliminary pharmacological evaluation. Med. Chem. Res. 2005, 14, 57-73.

90. Glennon, R.A.; Grella, B.; Tyacke, R.J.; Lau, A.; Westaway, J.; Hudson, A.L. Binding of $\beta$-carbolines at imidazoline I2 receptors: A structure-affinity investigation. Bioorg. Med. Chem. Lett. 2004, 14, 999-1002.

91. Poitout, L.; Roubert, P.; Contour-Galcera, M.; Moinet, C.; Lannoy, J.; Pommier, J.; Plas, P.; Bigg, D.; Thurieau, C. Identification of potent non-peptide somatostatin antagonists with Sst3 selectivity. J. Med. Chem. 2001, 44, 2990-3000. 
92. Pasternak, A.; Feng, Z.; de Jesus, R.; Ye, Z.; He, S.; Dobbelaar, P.; Bradley, S.A.; Chicchi, G.G.; Tsao, K.; Trusca, D.; et al. Stimulation of glucose-dependent insulin secretion by a potent, selective Sst3 antagonist. ACS Med. Chem. Lett. 2012, 3, 289-293.

93. Ganong, W., Ed. Review of Medical Physiology, 22nd ed.; Lange Medical Books/McGraw-Hill: New York, NY, USA, 2005; pp. 113-114.

94. Zhou, Y.; Li, J.; Wu, W.; Shang, J.; Thompson, J.R.; Thornberry, N.A. Diagnosis and Treatment of Type 2 Diabetes and Other Disorders. U.S. Patent 7,879,859, 2009.

95. Mjalli, A.M.M.; Andrews, R.C.; Xie, R.; Yarragunta, R.R.; Ren, T. Beta-Carboline Derivatives as PTP-Inhibitors. WO03033496A1, 24 April 2003.

96. Brandt, P.; Bremberg, U.; Crossley, R.; Graffner Nordberg, M.; Jenmalm Jensen, A.; Ringberg, E.; Ward, T. Novel Beta-Carbolines as Growth Hormone Secretagogue Receptor (GHSR) Antagonists. WO2005048916A2, 29 December 2005.

97. Hung, D.; Protter, A.; Chakravarty, S.; Jain, R.; Dugar, S. Pyrido[3,4-B]indoles and methods of use. WO2009120717, 3 December 2009.

98. Ortar, G.; Petrocellis, L.D.; Moriello, A.S.; Allarà, M.; Morera, E.; Nalli, M.; Marzo, V.D. Tetrahydro- $\beta$-Carboline derivatives targeting fatty acid amide hydrolase (FAAH) and transient receptor potential (TRP) channels. Bioorg. Med. Chem. Lett. 2013, 23, 138-142.

99. Bi, W.; Bi, L.; Cai, J.; Liu, S.; Peng, S.; Fischer, N.O.; Tok, J.B.-H.; Wang, G. Dual-acting agents that possess free radical scavenging and antithrombotic activities: Design, Synthesis, and evaluation of phenolic tetrahydro- $\beta$-carboline RGD peptide conjugates. Bioorg. Med. Chem. Lett. 2006, 16, 4523-4527.

100. Bi, W.; Cai, J.; Liu, S.; Baudy-Floc'h, M.; Bi, L. Design, Synthesis and cardioprotective effect of a new class of dual-acting agents: Phenolic tetrahydro- $\beta$-carboline RGD peptidomimetic conjugates. Bioorg. Med. Chem. 2007, 15, 6909-6919.

(C) 2014 by the authors; licensee MDPI, Basel, Switzerland. This article is an open access article distributed under the terms and conditions of the Creative Commons Attribution license (http://creativecommons.org/licenses/by/3.0/). 